\title{
Potensi Perlindungan Terhadap Ilmu Pengetahuan dan Teknologi oleh Dosen di Perguruan Tinggi dalam Peningkatan Daya Saing Global
}

\author{
Sudjana \\ Universitas Padjadjaran \\ Email : sdjana@yahoo.com
}

\begin{abstract}
This study discusses the potential of Intellectual Property protection on the creation of Science and Technology Development results by Lecturers in Higher Education and Intellectual Property Protection on the Creation of Science and Technology Development results in Universities in Improving Global Competitiveness. This study is a legal research using a normative juridical approach and descriptive analytical research specifications. The data used in this study are secondary data consisting of primary, secondary and tertiary legal materials. Data obtained through library studies and field research in the form of legislation, books, journals, and authoritative electronic media.

The results of the study show that (1). the results of Science and Technology Development by university lecturers have the potential to obtain wealth protection in the field of Copyright and Patents, but do not rule out rights through other types of Intellectual Property. (2). Creation of Science and Technology development results that are protected by Intellectual Property and supported by the value chain and competitive scope will have high quality and reputation so as to enhance global competitiveness.
\end{abstract}

Keywords: Intellectual Property, Science and Technology, Global Competitiveness

\section{PENDAHULUAN}

Negara Kesatuan Republik Indonesia memiliki tujuan sebagaimana diamanatkan dalam Pembukaan UUD 1945 yaitu “.melindungi segenap bangsa Indonesia dan seluruh tumpah darah Indonesia dan untuk memajukan kesejahteraan umum, mencerdaskan kehidupan bangsa, dan ikut melaksanakan ketertiban dunia yang berdasarkan kemerdekaan, perdamaian abadi, dan keadilan sosial...". ${ }^{124}$

Untuk mewujudkan tujuan tersebut, Pasal 31 Ayat (3) UUD 1945 mengamanatkan agar Pemerintah mengusahakan dan menyelenggarakan satu sistem pendidikan ${ }^{125}$ nasional yang meningkatkan keimanan dan ketakwaan kepada Tuhan Yang Maha Esa serta akhlak mulia dalam rangka mencerdaskan bangsa yang diatur dalam undang-undang. Selain itu pada Pasal 31 Ayat (5) mengamanahkan agar Pemerintah

\footnotetext{
${ }^{124}$ Pembukaan UUD 1945 Alinea IV

125 Pendidikan adalah usaha sadar dan terencana untuk mewujudkan suasana belajar dan proses pembelajaran agar peserta didik secara aktif mengembangkan potensi dirinya untuk memiliki kekuatan spiritual keagamaan, pengendalian diri, kepribadian, kecerdasan, akhlak mulia, serta keterampilan yang diperlukan dirinya, masyarakat, bangsa, dan Negara.
} 
memajukan Ilmu Pengetahuan ${ }^{126}$ dan Teknologi ${ }^{127}$ dengan menjunjung tinggi nilai-nilai agama dan persatuan bangsa untuk kemajuan peradaban serta kesejahteraan umat manusia. ${ }^{128}$ Hal ini mengingat kemajuan suatu negara dipengaruhi oleh kemampuan menguasai dan memanfaatkan ilmu pengetahuan dan teknologi untuk meningkatkan daya saing terutama di era globalisasi seperti pada saat ini. ${ }^{129}$

UU No. 20 Tahun 2003 Tentang Sistem Pendidikan Nasional memberikan kerangka yang jelas kepada Pemerintah dalam penyelenggaraan pendidikan nasional yang sesuai dengan amanat Pasal 31 Ayat (3) UD 1945. Namun berkaitan dengan pendidikan tinggi ${ }^{130}$ masih memerlukan pemberdayaan terhadap sivitas akademi (kususnya dosen) agar dapat lebih berfungsi dalam mengembangkan Ilmu Pengetahuan dan Teknologi dengan memperhatikan dan menerapkan nilai humaniora untuk pemberdayaan dan pembudayaan bangsa, ${ }^{131}$ serta dapat meningkatkan daya saing.

Berdasarkan data Global Competitiveness Index dari World Economic Forum 2016-2017, Indonesia menempati peringkat ke-41 dari 138 negara dengan pilar inovasi menduduki peringkat 31, subpilar kapasitas inovasi menduduki peringkat ke-32, subpilar belanja teknologi tinggi pemerintah peringkat ke-12, dan subpilar paten internasional menduduki peringkat ke-99. "Data tersebut menunjukkan bahwa inovasi yang dihasilkan masih berupa riset dasar yang belum dapat diaplikasikan dan dikomersialkan dalam dunia industri," sehingga diperlukan upaya-upaya peningkatan inovasi teknologi terapan yang lebih dapat diaplikasikan secara komersial, agar seluruh hasil inovasi tersebut dapat mendongkrak posisi daya saing Indonesia di kancah ekonomi global. Salah satu upayanya adalah penguatan dan pengembangan Kekayaan Inteklektual melalui perolehan paten atas invensi yang dihasilkan. Berdasarkan data World Intellectual Property Organization (WIPO), dari 9.153 paten yang terdaftar di Indonesia pada tahun 2015

126 Ilmu Pengetahuan adalah rangkaian pengetahuan yang digali, disusun, dan dikembangkan secara sistematis dengan menggunakan pendekatan tertentu, yang dilandasi oleh metodologi ilmiah untuk menerangkan gejala alam dan/atau kemasyarakatan tertentu.

127 Teknologi adalah penerapan dan pemanfaatan berbagai cabang Ilmu Pengetahuan yang menghasilkan nilai bagi pemenuhan kebutuhan dan kelangsungan hidup, serta peningkatan mutu kehidupan manusia.

${ }_{128}$ Penjelasan Umum UU No 12 Tahun 2012 Tentang Pendikdikan Tinggi.

${ }^{129}$ Bandingkan dengan Rais Rozali, "Pengelolaan Kekayaan Intelektual" tersedia dalam https://zalirais.wordpress.com/2013/09/10/pengelolaan-kekayaan-intelektual/ diakses 2 Januari 2019.

${ }^{130}$ Pendidikan Tinggi adalah jenjang pendidikan setelah pendidikan menengah yang mencakup program diploma, program sarjana, program magister, program doktor, dan program profesi, serta program spesialis, yang diselenggarakan oleh perguruan tinggi berdasarkan kebudayaan bangsa Indonesia.

131 Bandingkan dengan Rendy Ivaniar Fakultas Hukum Universitas Brawijaya http://www.scribd.com/ doc/ 100516733/Kajian-Kritis-Rancangan-Undang-undang-Pendidikan-Tinggi. diakses 5 Januari 2019. 
sebanyak 8.095 paten atau 89 persen merupakan paten yang berasal dari luar negeri, sedangkan paten dalam negeri hanya sebesar 1.058 paten. Hal tersebut menunjukkan masih banyaknya kendala yang perlu diatasi bersama dalam mengejar ketertinggalan dari negara maju. "Untuk mengejarnya, perlu upaya melalui peningkatan sumber daya manusia terutam dosen serta anggaran dan fasilitas riset yang memadai untuk mendorong terciptanya inovasi yang dapat diaplikasikan." Selama periode tahun 2005-2017, Kemenperin sudah menghasilkan 91 paten yang terdiri dari 79 paten dan 12 paten sederhana. Dari total tersebut, 37 paten tercatat sudah granted, 25 paten dalam tahap pemeriksaan substantif dan 29 paten lainnya masih dalam pemeriksaan administratif. ${ }^{132}$

UU No. 12 Tahun 2012 Tentang Pendidikan Tinggi seyogianya dapat memenuhi hal-hal yang berkaitan dengan : Pertama, penyelenggaraan Pendidikan Tinggi sebagai bagian yang tidak terpisahkan dari penyelenggaraan pendidikan nasional, tidak dapat dilepaskan dari amanat Pasal 31 Ayat (3) UUD 1945. Di samping itu dalam rangka menghadapi perkembangan dunia, Pendidikan Tinggi diharapkan mampu menjalankan peran strategis dalam memajukan peradaban dan kesejahteraan umat manusia, ${ }^{133}$ melalui pengembangan ilmu pengetahuan dan teknologi. Kedua, pada tataran praktis bangsa Indonesia juga tidak terlepas dari persaingan antar bangsa di satu pihak dan kemitraan dengan bangsa lain di pihak lain. Oleh karena itu, untuk meningkatkan daya saing bangsa dan daya mitra bangsa Indonesia dalam era globalisasi, diperlukan Pendidikan Tinggi yang mampu menghasilkan karya Penelitian dalam cabang Ilmu Pengetahuan dan Teknologi yang dapat diabdikan bagi kemaslahatan bangsa, negara, dan umat manusia, ${ }^{134}$ dan mendapat perlindungan Kekayaan Intelektual dalam rangka meningkat kualitas dan reputasi Perguruan Tinggi tersebut dan peneliti (terutama dosen) yang bersangkutan, sehingga dapat yang mengangkat martabat bangsa Indonesia dalam pergaulan internasional di era globalisasi. ${ }^{135}$

Berdasarkan latar belakang tersebut, maka identifikasi masalahnya adalah sebagai berikut:

132 Pramdia Arhando Julianto, "Hak Kekayaan Intelektual dan Inovasi Tingkatkan Daya Saing Industri" tersedia dalam https://ekonomi.kompas.com/read/2017/07/18/224443126/hak-kekayaanintelektual-dan-inovasi-tingkatkan-daya-saing-industri. diakses 7 Januari 2019.

133 Ibid.

134 Ibid.

135 Ibid. 
1. Bagaimana Potensi perlindungan Kekayaan Intelektual terhadap kreasi hasil Pengembangan Ilmu Pengetahuan dan Teknologi oleh dosen di Perguruan Tinggi?

2. Bagaimana Perlindungan Kekayaan Intelektual terhadap kreasi hasil Pengembangan Ilmu Pengetahuan dan Teknologi oleh dosen di Perguruan Tinggi dalam Peningkatan Daya Saing Global?

\section{METODE}

Penelitian ini menggunakan metode pendekatan Yuridis Normatif, yaitu penelitian dengan pendekatan yang lebih ditekankan pada data-data sekunder berupa bahan-bahan hukum primer, sekunder maupun tersier. Pada penelitian hukum normatif, bahan pustaka merupakan data dasar dalam (ilmu) penelitian yang digolongkan sebagai data sekunder. ${ }^{136}$ Spesifikasi penelitian ini adalah deskriptif analitis, yaitu penelitian yang bertujuan menggambarkan mengenai fakta-fakta disertai analisis yang akurat mengenai peraturan perundang-undangan yang berlaku baik nasional maupun internasional dihubungkan dengan teori-teori hukum yang berkaitan dengan pembangunan hukum. Soerjono Soekanto mengemukakan bahwa penelitian deskriptif yaitu memberikan data yang seteliti mungkin tentang manusia, keadaan dan gejala gejalan lainnya, dengan tujuan mempertegas hipotesa - hipoesa supaya dapat membantu dalam memperkuat teori - teori lama, atau dalam kerangka menyusun teori baru. ${ }^{137}$

Teknik pengumpulan data dilakukan melalui Penelitian kepustakaan dan Penelitian di lapangan. Penelitian kepustakaan dilakukan untuk memperoleh bahanbahan hukum baik primer, sekunder, maupun tersier. Bahan hukum primer adalah bahanbahan yang berasal dari peraturan perundang-undangan, konvensi internasional, perjanjian internasional yang relevan. Bahan hukum sekunder yakni terdiri dari doktrindoktrin, pendapat para ahli yang dapat terlihat dalam buku-buku hukum dan makalahmakalah yang ditulis oleh para ahli, karangan berbagai panitia pembentukan hukum, hasil penelitian hukum, RUU dan lain-lain yang dapat memberikan penjelasan mengenai bahan hukum primer. Di samping itu dikaji pula bahan hukum tersier, yakni berupa

\footnotetext{
136 Soerjono Soekanto dan Sri Maudji, Penelitian Hukum Normatif Suatu Tinjauan Singkat, Jakarta: Raja Grafindo Persada, 1985, hlm 24

137 Soerjono Soekanto, Pengantar Penelitian Hukum, Jakarta: Universitas Indonesia Press, 1984, hlm 10 .
} 
pendapat-pendapat atau opini masyarakat yang ada di dalam majalah-majalah dan surat kabar, kamus, ensiklospedi, yang dapat memberikan petujuk maupun penjelasan terhadap bahan hukum primer maupun sekunder.

Teknis Analisis data yang digunakan dalam penelitian ini adalah deskriptif analisis normatif, yakni pemaparan dan penggambaran peraturan perundang-undangan yang berkitan dengan pembentukan hukum yang dianalsis berdasarkan teori-teori hukum.

\section{PEMBAHASAN}

\subsection{Potensi perlindungan Kekayaan Intelektual terhadap kreasi hasil} Pengembangan Ilmu Pengetahuan dan Teknologi oleh dosen di Perguruan

\section{Tinggi}

Pendidikan Tinggi berfungsi antara lain mengembangkan Ilmu Pengetahuan dan Teknologi dengan memperhatikan dan menerapkan nilai Humaniora, ${ }^{138}$ dan bertujuan antara lain.....dihasilkannya Ilmu Pengetahuan dan Teknologi melalui Penelitian yang memperhatikan dan menerapkan nilai Humaniora agar bermanfaat bagi kemajuan bangsa, serta kemajuan peradaban dan kesejahteraan umat manusia ${ }^{139}$, sedangkan Perguruan Tinggi melaksanakan fungsi dan peran antara lain sebagai: ${ }^{140}$ pusat pengembangan Ilmu Pengetahuan dan Teknologi, yang dilaksanakan melalui kegiatan Tridharma yang ditetapkan dalam statuta Perguruan Tinggi.

Berkaitan dengan fungsi Perguruan Tinggi, dosen sebagai sivitas akademika, ${ }^{141}$ bertujuan mengembangkan inovasi melalui kreasinya, dalam arti keakhlian yang dimilikinya berfungsi untuk melahirkan kreasi baru (inovasi) dalam bentuk yang disebut Kekayaan Intelektual, sehingga terwujudnya Pengabdian kepada Masyarakat berbasis penalaran dan karya Penelitian yang bermanfaat dalam memajukan kesejahteraan umum dan terus dilakukan sebagai pembudayaan dan pemberdayaan bangsa yang berlangsung sepanjang hayat sejalan dengan prinsip Perguruan Tinggi. ${ }^{142}$

138 Selengkapnya, lihat Pasal 4 point ... UU No 12 Tahun 2012.

${ }^{139}$ Ibid, Pasal 5.

${ }^{140}$ Ibid, Pasal 58.

${ }^{141}$ Ibid, Pasal 1 Angka 13 berbunyi: "Sivitas Akademika adalah masyarakat akademik yang terdiri atas dosen dan mahasiswa."

${ }^{142}$ Ibid, Pasal 6 huruf d. 
Dalam kaitan dengan hasil pengembangan Ilmu Pengetahuan dan Teknologi oleh dosen di Perguruan Tinggi, kreasi tersebut dapat menjadi obyek perlindungan Kekayaan Intelektual terutama Hak Cipta (untuk ilmu pengetahuan) dan Paten (untuk teknologi), tetapi tidak menutup kemungkinan mendapat hak melalui jenis Kekayaan intelektual lainnya. ${ }^{143}$ Dosen adalah pendidik profesional dan ilmuwan dengan tugas utama mentransformasikan, mengembangkan, dan menyebarluaskan Ilmu Pengetahuan dan Teknologi melalui Pendidikan, Penelitian, dan Pengabdian kepada Masyarakat. ${ }^{144}$ Kedudukan dosen sebagai tenaga profesional berfungsi untuk meningkatkan martabat dan peran dosen sebagai agen pembelajaran, pengembang ilmu pengetahuan, teknologi, dan seni, serta pengabdi kepada masyarakat berfungsi untuk meningkatkan mutu pendidikan nasional. ${ }^{145}$ Profesional adalah pekerjaan atau kegiatan yang dilakukan oleh seseorang dan menjadi sumber penghasilan kehidupan yang memerlukan keahlian, kemahiran, atau kecakapan yang memenuhi standar mutu atau norma tertentu serta memerlukan pendidikan profesi. ${ }^{146}$

Dosen memiliki tugas mentransformasikan Ilmu Pengetahuan dan/atau Teknologi yang dikuasainya kepada Mahasiswa dengan mewujudkan suasana belajar dan pembelajaran sehingga Mahasiswa aktif mengembangkan potensinya dan Dosen sebagai ilmuwan memiliki tugas mengembangkan suatu cabang Ilmu Pengetahuan dan/atau Teknologi melalui penalaran dan penelitian ilmiah serta menyebarluaskannya. Dosen secara perseorangan atau berkelompok wajib menulis buku ajar atau buku teks, yang diterbitkan oleh Perguruan Tinggi dan/atau publikasi ilmiah sebagai salah satu sumber belajar dan untuk pengembangan budaya akademik serta pembudayaan kegiatan baca tulis bagi Sivitas Akademika.

Tugas dan kewajiban dosen dalam mengembangkan ilmu pengetahuan dan teknologi sehingga menghasilkan kreasi yang asli dan baru merupakan bentuk kepemilikan terhadap hasil pemikiran intelektualitas manusia yang mendapat perlindungan berdasarkan hukum kekayaan Intelektual. Dalam kaitan ini, terdapat dua teori secara filsafati mengenai anggapan hukum bahwa kekayaan intelektual adalah suatu sistem kepemilikan (property). Teori tersebut dikemukakan oleh John Locke yang

${ }^{143}$ Lingkup Kekayaan Intelektual dibagi kedalam 2 (dua) bagian atau jenis, yaitu: (1).Hak Cipta dan Hak terkait; (2). Kekayaan Perindustrian, yaitu : Paten; merek; Rahasia Dagang, Desain Industri; Perlindungan Varietas Tanaman; dan Desain Tata Letak Sirkuit Terpadu.

${ }^{144}$ Pasal 1 Angka 14 UU No 12 Tahun 2012.

145 Pasal 5 UU No 14 Tahun 2005 Tentang Guru dan Dosen.

${ }^{146}$ Ibid, Pasal 1 Angka 4. 
berpengaruh di negara penganut sistem hukum common law dan Hegel yang sangat berpengaruh pada negara-negara penganut sistem hukum civil law, bermula dari teori hukum alam yang bersumber pada moralitas tentang apa yang baik dan apa yang buruk. John Locke mengajarkan konsep kepemilikan kaitannya hak asasi manusia. Locke menyatakan bahwa pada awalnya tidak ada hukum positif yang mengatur masalah kepemilikan (status naturalis), namun kemudian status naturalis tidak dapat dipertahankan karena negara tidak memiliki hakim yang dapat memberikan terjemahan terhadap pertentangan kepentingan antar individu. Status civilis adalah bentuk pengamanan bagi hak-hak alamiah yang tidak tersedia dalam status naturalis. Pada prinsipnya setiap orang tidak diperkenankan untuk merugikan orang lain, sehingga setiap individu memiliki hak alami (natural right) untuk memiliki buah atas jerih payahnya. ${ }^{147}$ Karya intelektual dapat terwujud, bukan secara tiba-tiba namun melalui proses pemikiran, perenungan, uji coba, dan akhirnya membentuk hasil. Proses berkarya tersebut dimaknai oleh labor theory sebagai hak untuk menguasai invensi tersebut, sehingga orang lain dilarang mengakui invensi orang lain. Inventor/pendesain/pencipta telah bersusah payah untuk mewujudkan karya kekayaan intelektualnya, oleh karena itu patut diberikan kepadanya balas jasa atas karyanya. Hubungan timbal balik antara inventor/pendesain/pencipta dengan orang yang mengambil manfaat dari hasil karya, dalam teori pertukaran sosial (social exchange theory) sangat penting untuk dilakukan agar inventor/pendesain/pencipta termotivasi menghasilkan karya baru. ${ }^{148}$

Hak Cipta adalah hak eksklusif pencipta yang timbul secara otomatis berdasarkan prinsip deklaratif setelah suatu ciptaan diwujudkan dalam bentuk nyata tanpa mengurangi pembatasan sesuai dengan ketentuan peraturan perundang-undangan. "hak eksklusif" adalah hak yang hanya diperuntukkan bagi Pencipta, sehingga tidak ada pihak lain yang dapat memanfaatkan hak tersebut tanpa izin Pencipta. Hak eksklusif terdiri atas hak moral dan hak ekonomi. Hak moral merupakan hak yang melekat secara abadi pada diri Pencipta untuk: ${ }^{149}$

147 Rahmi Jened Parinduri Nasution, Interface Hukum Kekayaan Intelektual dan Hukum Persaingan (Penyalahgunaan HKI), Rajawali Press, Jakarta, 2013, hlm 26.

148 Candra Irawan, Politik Hukum Hak Kekayaan Intelektual Indonesia : Kritik Terhadap WTO/TRIP's Agreement dan Upaya Membangun Hukum Kekayaan Intelektual Demi Kepentingan Nasional. (Bandung : Mandar Maju, 2011), p. 29. lihat juga Mieke Yustia Ayu Ratna Sari, "Pembangunan Kekayaan Intelektual (KI) Berbasis Teknologi Informasi Di Era Global", tersedia dalam https://media.neliti.com/media/publications/172839-ID-pembangunan-kekayaan-intelektual-ki-berb.pdf diakses 8 Januari 2019.

${ }^{149}$ Pasal 1 Angka 1 UU No 28 Tahun 2014 Tentang Hak Cipta. 
"a. tetap mencantumkan atau tidak mencantumkan namanya pada salinan sehubungan dengan pemakaian Ciptaannya untuk umum;

b. menggunakan nama aliasnya atau samarannya;

c. mengubah Ciptaannya sesuai dengan kepatutan dalam masyarakat;

d. mengubah judul dan anak judul Ciptaan; dan

e. mempertahankan haknya dalam hal terjadi distorsi Ciptaan, mutilasi Ciptaan, modifikasi Ciptaan, atau hal yang bersifat merugikan kehormatan diri atau reputasinya."

Contoh: seorang dosen yang menulis disertasi untuk program doktornya, dapat mengubah judul atau isi disertasi tersebut agar sesuai dengan format sebuah buku. Hak moral tidak dapat dialihkan selama Pencipta masih hidup, tetapi pelaksanaan hak tersebut dapat dialihkan dengan wasiat atau sebab lain sesuai dengan ketentuan peraturan perundang-undangan setelah Pencipta meninggal dunia. Dalam hal terjadi pengalihan pelaksanaan hak moral, penerima dapat melepaskan atau menolak pelaksanaan haknya dengan syarat pelepasan atau penolakan pelaksanaan hak tersebut dinyatakan secara tertulis.

Hak ekonomi merupakan hak eksklusif Pencipta atau Pemegang Hak Cipta untuk mendapatkan manfaat ekonomi atas Ciptaan untuk melakukan:

a. penerbitan Ciptaan;

b. Penggandaan Ciptaan dalam segala bentuknya;

c. penerjemahan Ciptaan;

d. pengadaptasian, pengaransemenan, atau pentransformasian Ciptaan;

e. Pendistribusian Ciptaan atau salinannya;

f. pertunjukan Ciptaan;

g. Pengumuman Ciptaan;

h. Komunikasi Ciptaan; dan

i. penyewaan Ciptaan. Setiap Orang yang melaksanakan hak ekonomi wajib mendapatkan izin Pencipta atau Pemegang Hak Cipta sehingga tanpa izin Pencipta atau Pemegang Hak Cipta dilarang melakukan Penggandaan dan/atau Penggunaan Secara Komersial Ciptaan.

Contoh: seorang dosen Perguruan Tinggi yang menulis sebuah buku yang diterbitkan oleh sebuah penerbit berhak atas hak ekonomi atas penerbitan hak cipta tersebut, baik berdasarkan sistem royalti maupun jual putus (sold flat). Namun, Ciptaan buku, dan/atau semua hasil karya tulis lainnya, lagu dan/atau musik dengan atau tanpa teks yang dialihkan dalam perjanjian jual putus dan/atau pengalihan tanpa batas waktu, 
Hak Ciptanya beralih kembali kepada Pencipta pada saat perjanjian tersebut mencapai jangka waktu 25 (dua puluh lima) tahun. ${ }^{150}$

Pemegang Hak Cipta yang bukan Pencipta hanya memiliki sebagian dari hak eksklusif berupa hak ekonomi ${ }^{151}$, sedangkan Pencipta adalah seorang atau beberapa orang yang secara sendiri-sendiri atau bersama-sama menghasilkan suatu ciptaan yang bersifat khas dan pribadi. Ciptaan adalah setiap hasil karya cipta di bidang ilmu pengetahuan, seni, dan sastra yang dihasilkan atas inspirasi, kemampuan, pikiran, imajinasi, kecekatan, keterampilan, atau keahlian yang diekspresikan dalam bentuk nyata. Ciptaan yang dilindungi meliputi Ciptaan dalam bidang ilmu pengetahuan, seni, dan sastra, terdiri atas:

“a. buku, pamflet, perwajahan karya tulis yang diterbitkan, dan semua hasil karya tulis lainnya;

b. ceramah, kuliah, pidato, dan Ciptaan sejenis lainnya;

c. alat peraga yang dibuat untuk kepentingan pendidikan dan ilmu pengetahuan;

d. lagu dan/atau musik dengan atau tanpa teks;

e. drama, drama musikal, tari, koreografi, pewayangan, dan pantomim;

f. karya seni rupa dalam segala bentuk seperti lukisan, gambar, ukiran, kaligrafi, seni pahat, patung, atau kolase;

g. karya seni terapan;

h. karya arsitektur;

i. peta;

j. karya seni batik atau seni motif lain;

k. karya fotografi;

1. Potret;

m.karya sinematografi;

n. terjemahan, tafsir, saduran, bunga rampai, basis data, adaptasi, aransemen, modifikasi dan karya lain dari hasil transformasi;

o. terjemahan, adaptasi, aransemen, transformasi, atau modifikasi ekspresi budaya tradisional;

p. kompilasi Ciptaan atau data, baik dalam format yang dapat dibaca dengan Program Komputer maupun media lainnya;

q. kompilasi ekspresi budaya tradisional selama kompilasi tersebut merupakan karya yang asli;

r. permainan video; dan

s. Program Komputer."

150 Ibid, Penjelasan Pasal 18 :" Yang dimaksud dengan "hasil karya tulis lainnya" antara lain naskah kumpulan puisi, kamus umum, dan Harian umum surat kabar. Yang dimaksud dengan "jual putus" adalah perjanjian yang mengharuskan Pencipta menyerahkan Ciptaannya melalui pembayaran lunas oleh pihak pembeli sehingga hak ekonomi atas Ciptaan tersebut beralih seluruhnya kepada pembeli tanpa batas waktu, atau dalam praktik dikenal dengan istilah sold flat."

151 Ibid, Penjelasan Pasal 4. 
Kreasi hasil pengembangan ilmu pengetahuan oleh dosen di Perguruan Tinggi merupakan potensi Hak Cipta, berkaitan dengan antara lain buku, perwajahan karya tulis yang diterbitkan, dan semua hasil karya tulis lainnya; ceramah, kuliah, pidato, dan Ciptaan sejenis lainnya; alat peraga yang dibuat untuk kepentingan pendidikan dan ilmu pengetahuan, yang mendapat perlindungan selama 70 tahun setelah Pencipta meninggal dunia, terhitung mulai tanggal 1 Januari tahun berikutnya. Dalam hal Ciptaan dimiliki oleh 2 (dua) orang atau lebih, pelindungan Hak Cipta berlaku selama hidup Pencipta yang meninggal dunia paling akhir dan berlangsung selama 70 (tujuh puluh) tahun sesudahnya, terhitung mulai tanggal 1 Januari tahun berikutnya. Kreasi dosen berupa terjemahan, tafsir, saduran, bunga rampai, basis data, adaptasi, aransemen, modifikasi dan karya lain dari hasil transformasi; terjemahan, adaptasi, aransemen, transformasi atau modifikasi ekspresi budaya tradisional; kompilasi Ciptaan atau data, baik dalam format yang dapat dibaca dengan Program Komputer atau media lainnya; dan kompilasi ekspresi budaya tradisional selama kompilasi tersebut merupakan karya yang asli, berlaku selama 50 (lima puluh) tahun sejak pertama kali dilakukan Pengumuman.

Hasil karya yang tidak dilindungi Hak Cipta meliputi antara lain hasil karya yang belum diwujudkan dalam bentuk nyata; setiap ide, prosedur, sistem, metode, konsep, prinsip, temuan atau data walaupun telah diungkapkan, dinyatakan, digambarkan, dijelaskan, atau digabungkan dalam sebuah Ciptaan. Dengan demikian, buku yang ditulis oleh dosen yang masih dalam konsep, dan karya ilmiah lainnya yang belum berwujud tidak dapat dilindungi melalui rezim Hak Cipta.

Penggunaan, pengambilan, Penggandaan, dan/atau pengubahan suatu Ciptaan dan/atau produk Hak Terkait secara seluruh atau sebagian yang substansial tidak dianggap sebagai pelanggaran Hak Cipta jika sumbernya disebutkan atau dicantumkan secara lengkap untuk keperluan: antara lain: pendidikan, penelitian, penulisan karya ilmiah, penyusunan laporan, penulisan kritik atau tinjauan suatu masalah dengan tidak merugikan kepentingan yang wajar dari Pencipta atau Pemegang Hak Cipta; ceramah yang hanya untuk tujuan pendidikan dan ilmu pengetahuan dengan ketentuan tidak merugikan kepentingan yang wajar dari Pencipta (dosen yang bersangkutan). "Kepentingan yang wajar" atas pengecualian hak cipta yang didasarkan pada keseimbangan dalam menikmati manfaat ekononomi atas suatu ciptaan. ${ }^{152}$ Ketentuan tentang kepentingan yang wajar (fair use) merupakan asas Anglo Saxon yang diadopsi ke 
dalam sistem hukum Indonesia (sebagai warisan sistem di Eropa Kontinental). Namun terlepas dari perbedaan sistem hukum, kepentingan yang wajar dalam pengecualian hak cipta masih tetap tidak jelas parameter pengecualiannya. Jika melihat ketentuan dalam 17 U.S.C. $§ 107$ Undang-Undang Hak Cipta Amerika Serikat, parameter yang menjadi pengecualiannya jelas, yaitu: (1) tidak diperuntukan untuk sarana komersial, (2) tidak mengubah sifat dari hak cipta itu sendiri, (3) jumlah yang digunakan, dan (4) tidak mempengaruhi pasar dari hak cipta itu sendiri. Dari ketentuan fair use di Amerika Serikat maka batasan dari pengecualian hak cipta memiliki parameter yang jelas. Sebaliknya, pengaturan fair use di Indonesia dalam Pasal 44 Undang-Undang No. 28 Tahun 2014 masih tidak jelas batasan dari 'kepentingan yang wajar' sehingga perlu ditafsirkan apabila terjadi sengketa hukum di kemudian hari dengan bertolak pada kalimat 'keseimbangan dalam menikmati manfaat ekonomi dst...' 153

Dengan demikian, hasil pengembangan Ilmu Pengetahuan di Perguruan Tinggi yang dilakukan dengan mengambil sumber dari pihak lain dan untuk ceramah yang hanya untuk tujuan pendidikan dan ilmu pengetahuan bukan merupakan pelanggaran jika sumbernya disebutkan atau dicantumkan secara lengkap, misalnya untuk sumber dari buku, perlu disebutkan nama penulis, judul, kota dan nama penerbit, tahun penerbitan, dan halaman tetapi dengan mengingat pada keseimbangan dalam menikmati manfaat ekonomi atas suatu ciptaan.

Hasil pengembangan teknologi di Perguruan Tinggi oleh dosen berpotensi untuk mendapat perlindungan paten, yaitu hak eksklusif yang diberikan oleh negara kepada inventor atas hasil invensinya di bidang teknologi untuk jangka waktu tertentu melaksanakan sendiri invensi tersebut atau memberikan persetujuan kepada pihak lain untuk melaksanakannya. Invensi adalah ide inventor yang dituangkan ke dalam suatu kegiatan pemecahan masalah yang spesifik di bidang teknologi berupa produk atau proses, atau penyempurnaan dan pengembangan produk atau proses. ${ }^{154}$ Inventor adalah seorang atau beberapa orang yang secara bersama-sama melaksanakan ide yang dituangkan ke dalam kegiatan yang menghasilkan Invensi. ${ }^{155}$

${ }^{153}$ Bambang Pratama, "Fair Use VS. Penggunaan yang Wajar dalam Hak Cipta". Tersedia dalam http://Business-Law.Binus.ac.id/2015/01/31/Fair-Use-VS-Penggunaan-yang-Wajar-dalam-Hak-Cipta/ diakses 15 Januari 2016.

${ }^{154}$ Pasal 1 Angka 2 UU No 13 Tahun 2016 Tentang Paten.

${ }^{155}$ Ibid, Pasal 1 Angka 3. 
Paten diberikan untuk Invensi yang baru, mengandung langkah inventif, dan dapat diterapkan dalam industri. Invensi dianggap baru jika pada Tanggal Penerimaan, Invensi tersebut tidak sama dengan teknologi yang diungkapkan sebelumnya. Teknologi yang diungkapkan sebelumnya merupakan teknologi yang telah diumumkan di Indonesia atau di luar Indonesia dalam suatu tulisan, uraian lisan atau melalui peragaan, penggunaan, atau dengan cara lain yang memungkinkan seorang ahli untuk melaksanakan Invensi tersebut sebelum: a. Tanggal Penerimaan; atau b. tanggal prioritas dalam hal Permohonan diajukan dengan Hak Prioritas. Teknologi yang diungkapkan sebelumnya mencakup dokumen Permohonan lain yang diajukan di Indonesia yang dipublikasikan pada atau setelah Tanggal Penerimaan yang pemeriksaan substantifnya sedang dilakukan, tetapi Tanggal Penerimaan tersebut lebih awal daripada Tanggal Penerimaan atau tanggal prioritas Permohonan. Invensi tidak dianggap telah diumumkan jika dalam waktu paling lama 6 (enam) bulan sebelum Tanggal Penerimaan, Invensi telah: a. dipertunjukkan dalam suatu pameran resmi atau dalam suatu pameran yang diakui sebagai pameran resmi, baik yang diselenggarakan di Indonesia maupun di luar negeri; b. digunakan di Indonesia atau di luar negeri oleh Inventornya dalam rangka percobaan dengan tujuan penelitian dan pengembangan; dan/ atau c. diumumkan oleh Inventornya dalam: 1. sidang ilmiah dalam bentuk ujian dan/ atau tahap ujian skripsi, tesis, disertasi, atau karya ilmiah lain; dan/atau 2. forum ilmiah lain dalam rangka pembahasan hasil penelitian di lembaga pendidikan atau lembaga penelitian. Invensi juga tidak dianggap telah diumumkan apabila dalam waktu 12 (dua belas) bulan sebelum Tanggal Penerimaan, ada pihak lain yang mengumumkan dengan cara melanggar kewajiban untuk menjaga kerahasiaan Invensi tersebut. Invensi mengandung langkah inventif jika Invensi tersebut bagi seseorang yang mempunyai keahlian tertentu di bidang teknik merupakan hal yang tidak dapat diduga sebelumnya. Untuk menentukan suatu Invensi merupakan hal yang tidak dapat diduga sebelumnya harus dilakukan dengan memperhatikan keahlian yang ada pada saat Permohonan diajukan atau yang telah ada pada saat diajukan permohonan pertama dalam hal Permohonan itu diajukan dengan Hak Prioritas. Invensi dapat diterapkan dalam industri jika Invensi tersebut dapat dilaksanakan dalam industri sebagaimana diuraikan dalam Permohonan.

Paten diberikan untuk jangka waktu 20 (dua puluh) sedangkan paten sederhana 10 (sepuluh) tahun tahun terhitung sejak Tanggal Penerimaan. Jangka waktu tersebut 
tidak dapat diperpanjang. Tanggal mulai dan berakhirnya jangka waktu Paten dicatat ${ }^{156}$ dan diumumkan melalui media elektronik ${ }^{157}$ dan/atau media non-elektronik. ${ }^{158}$

Invensi yang tidak dapat diberi Paten meliputi: a. proses atau produk yang pengumuman, penggunaan, atau pelaksanaannya bertentangan dengan peraturan perundang-undangan, agama, ketertiban umum, atau kesusilaan; b. metode pemeriksaan, perawatan, pengobatan dan/ atau pembedahan yang diterapkan terhadap manusia dan/atau hewan; c. teori dan metode ${ }^{159}$ di bidang ilmu pengetahuan dan matematika; $d$. makhluk hidup, kecuali jasad renik; atau e. proses biologis yang esensial untuk memproduksi tanaman atau hewan, kecuali proses nonbiologis atau proses mikrobiologis.

Pihak yang berhak memperoleh Paten adalah Inventor atau Orang yang menerima lebih lanjut hak Inventor yang bersangkutan. Jika Invensi dihasilkan oleh beberapa orang secara bersama-sama, hak atas Invensi dimiliki secara bersama-sama oleh para Inventor yang bersangkutan. Dalam kaitan dengan pengembangan teknologi oleh seorang dosen, maka ia dianggap inventor ${ }^{160}$ atau apabila paten tersebut oleh dosen yang bersangkutan dialihkan melalui perjanjian lisensi kepada pihak lain (PT X), maka PT X berkedudukan sebagai pemegang paten. Dalam hal hasil pengembang tersebut dihasilkan oleh beberapa dosen di Perguruan Tiggi yang bersangkutan, maka pemegang paten adalah secara bersama-sama.

Pemegang Paten atas Invensi yang dihasilkan oleh Inventor dalam hubungan kerja merupakan pihak yang memberikan pekerjaan, kecuali diperjanjikan lain. Ketentuan sebagaimana dimaksud juga berlaku terhadap Invensi yang dihasilkan, baik oleh karyawan maupun pekerja yang menggunakan data dan/atau sarana yang tersedia dalam pekerjaannya. Inventor tersebut berhak mendapatkan Imbalan berdasarkan perjanjian yang dibuat oleh pihak pemberi kerja dan Inventor, dengan memperhatikan

156 dicatat dalam daftar umum Paten.

157 "media elektronik" adalah media yang menggunakan elektronik atau energi elektro mekanis untuk mengakses kontennya, misalnya situs internet.

158 "media non-elektronik" berupa penempatan dalam berita resmi Paten yang diterbitkan secara berkala oleh Menteri, penempatan pada media khusus yang dengan mudah serta jelas dapat dilihat oleh masyarakat, antara lain cetakan berkala yang diterbitkan oleh Direktorat Jenderal Kekayaan Intelektual dan/atau papan pengumuman di kantor Menteri

159 Teori dan metode di bidang ilmu pengetahuan dan matematik tidak dapat diberikan paten karena bersifat teoritis bukan praktis untuk digunakan dalam dunia industri, tetapi perlindungan terhadap kreasi tersebut dapat dilakukan melalui Hak Cipta.

${ }^{160} \mathrm{Ibid}$, Pasal 11 Kecuali terbukti lain, pihak yang dianggap sebagai Inventor adalah seorang atau beberapa orang yang untuk pertama kali dinyatakan sebagai Inventor dalam Permohonan. 
manfaat ekonomi yang diperoleh dari Invensi dimaksud. Imbalan dapat dibayarkan berdasarkan: a. jumlah tertentu dan sekaligus; b. persentase; c. gabungan antara jumlah tertentu dan sekaligus dengan hadiah atau bonus; atau d. bentuk lain yang disepakati para pihak. Dalam hal tidak terdapat kesesuaian mengenai cara perhitungan dan penetapan besarnya Imbalan, para pihak dapat mengajukan gugatan ke Pengadilan Niaga. Ketentuan tersebut tidak menghapuskan hak Inventor untuk tetap dicantumkan namanya dalam sertifikat Paten. sebagai contoh Dosen A bekerja pada sebuah Perguruan Tinggi swasta, berdasarkan perjanjian yang dibuat bertugas untuk membuat kreasi yang berpotensi untuk diberikan paten. dalam kasus tersebut, pemegang paten adalah Perguruan Tinggi Swasta yang bersangkutan kecuali diperjanjikan lain dan Dosen yang bersangkutan berhak atas imbalan sesuai kesepakatan tetapi dosen tidak menghapuskan hak Inventor (dosen yang bersangkutan) untuk tetap dicantumkan namanya dalam sertifikat Paten.

Pemegang Paten atas Invensi yang dihasilkan oleh Inventor dalam hubungan dinas dengan instansi pemerintah adalah instansi pemerintah dimaksud dan Inventor, kecuali diperjanjikan lain. Setelah Paten dikomersialkan, Inventor berhak mendapatkan Imbalan atas Paten yang dihasilkannya dari sumber penerimaan negara bukan pajak. Dalam hal instansi pemerintah sebagai Pemegang Paten tidak dapat melaksanakan Patennya, Inventor atas persetujuan Pemegang Paten dapat melaksanakan Paten dengan pihak ketiga. Terhadap pelaksanaan Paten sebagaimana dimaksud selain instansi pemerintah, Inventor memperoleh Royalti dari pihak ketiga yang mendapatkan manfaat ekonomi dari komersialisasi Paten tersebut. Ketentuan sebagaimana dimaksud tidak menghapuskan hak Inventor untuk tetap dicantumkan namanya dalam sertifikat Paten. Contoh : B seorang dosen disebuah Perguruan Tinggi Negeri X di kota Z menghasilkan teknologi baru menggunakan fasilitas atau dana dari Perguruan Tinggi yang bersangkutan, maka pemegang paten adalah Perguruan Tinggi X, sedangkan dosen sebagai inventor. Namun, yang menjadi masalah apakah ketentuan tersebut berlaku juga apabila teknologi yang dihasilkan oleh dosen tersebut tidak menggunakan dana atau fasilitas Negara (Perguruan Tinggi X)? tetapi melakukan penelitian mandiri?. Ketentuan UU No 13 Tahun 2016 tidak mengatur secara tegas mengenai hal tersebut, sehingga makna "hubungan dinas" perlu ditafsirkan secara "gramatikal" atau penafsiran tata bahasa, yaitu hubungan antara dosen dengan Perguruan Tinggi Negeri (Instansi Pemerintah) atau Perguruan Tinggi swasta yang dana atau fasilitasnya berasal dari 
pemerintah (misalnya hibah penelitian dari Kementerian Riset Teknologi dan PendidikanTinggi).

\subsection{Perlindungan Kekayaan Intelektual Terhadap Kreasi Hasil Pengembangan Ilmu Pengetahuan Dan Teknologi Di Perguruan Tinggi Dalam Peningkatan Daya Saing Global}

Konsep daya saing umumnya dikaitkan dengan konsep comparative advantage, yakni dimilikinya unsur-unsur penunjang proses produksi yang memungkinkan satu negara menarik investor untuk melakukan investasi ke negaranya, tidak ke negara yang lain. Konotasi advantage di sini adalah situasi yang memungkinkan pemodal menuai keuntungan semaksimal mungkin. Misalnya dengan menyediakan lahan murah, upah buruh murah, dan suplai bahan mentah produksi yang terjamin kontinyuitasnya dengan hatpa yang lebih murah daripada harga yang ditawarkan oleh negara lain. Artinya, kekuatan modal dan keunggulan teknologi menjadi kunci penentu peningkatan daya saing (penjualan produk) satu negara. Sayang di saat bangsa-bangsa di dunia ini mulai menapaki era baru, negara-negara sedang berkembang (termasuk Indonesia) umumnya lemah di kedua elemen terakhir ini. Melalui kelemahan ini kepentingan negara berkembang dikendalikan oleh kepentingan negara maju. Artinya dilihat dari sudut kepentingan negara sedang berkembang, konsep comparative advantage ini lebih tepat dibaca sebagai comparative disadvantage. Bila dikaitkan dengan sudut pandang politik, selain elemen teknologi dan modal, elemen penting lain dari daya saing adalah adanya kompetisi, khususnya kompetisi internal. Maksudnya, sebelum produk yang dihasilkan oleh satu bangsa dikonteskan dengan produk bangsabangsa lain, harus dipastikan bahwa produk itu sudah dikonteskan di antara elemen-elemenbangsa itu sendiri. Artinya, untuk bisa benar-benar menghasilkan produk unggulan, atau aktor yang handal untuk "mewakili" bangsa di pentas internasional, perIu diciptakan kompetisi di tiap tingkatan masyarakat.Prinsipsurvivalof thefittest (siapayang kuat maka dia yang akan bertahan) berIaku disini. Hanya melalui kompetisi internal maka satu bangsa dapat survive pada kompetisi regional maupun global. ${ }^{161}$

161 Riswandha Imawan, Peningkatan Daya Saing: "Pendekatan Paradigmatik- Politis, Volume 6, Nomor I, Juli 2002 (79-104)" tersedia dalam file://C:/Users/kiki/Downloads/11095-21113-1PB\%20(2).pdf diakses 17 Januari 2018. 
Indikator untuk mengukur daya saing, dapat digunakan 2 konsep, yaitu pangsa pasar dan keuntungan. Pangsa pasar teknologi yang diberikan paten ditentukan oleh 4 faktor yaitu: ${ }^{162}$

“a. Faktor yang dikontrol oleh perusahaan perseorangan, yaitu strategi, produksi, teknologi, pelatihan, $R \& D$, biaya produksi, serta hubungan kerja.

b. Faktor yang dikontrol oleh pemerintah, mencakup lingkungan bisnis (pajak, suku bunga, dan nilai tukar), kebijakan perdagangan internasional, kebijakan R\&D, pendidikan dan latihan, hubungan kerja, dan regulasi- regulasi / standar.

c. Faktor yang semi dikontrol, yaitu harga input, dan kondisi penawaran.

d. Faktor yang tidak dapat dikontrol, meliputi lingkungan alam.

Paten merupakan kreasi dan inovasi di bidang teknologi sebagai hasil riset dan pengembangan (R\&D) yang memerlukan biaya produksi merupakan faktor yang dikontrol oleh perusahaan perseorangan dan pemerintah. Selain itu, faktor yang dikontrol oleh pemerintah berupa regulasi terhadap paten sebagaimana diatur dalam UU.No.13 Tahun 2016. Kemudian berkaitan dengan faktor yang semi dikontrol terhadap paten adalah harga input yaitu harga yang dijual kepada konsumen berdasarkan kondisi penawaran dari pemegang hak. Sedangkan untuk faktor yang tidak dapat dikontrol adalah lingkungan alam, yang dalam hal ini tidak signifikan untuk paten karena teknologi tidak tergantung secara langsung pada lingkungan alam, misalnya tanah. Apabila keempat faktor ini dapat berjalan dengan baik, maka menjadi daya dukung bagi pangsa pasar paten dan meningkatkan keuntungan sehingga terjadi peningkatan daya saing.

Daya saing dari perspektif keuntungan dan pangsa pasar meliputi rasio orientasi ekspor, rasio orientasi impor, dan rasio orientasi ekspor neto. Sedangkan keuntungan mencakup pertambahan nilai sebagai rasio dari harga penjualan, jumlah karyawan, biaya tenaga kerja, dan jumlah perusahaan. Hal itu dapat dijelaskan melalui berbagai faktor, yaitu produktivitas, kreasi teknologi, produk, masukan dan biaya, struktur industri, kondisi permintaan, dan hubungan. ${ }^{163}$

Kemampuan daya saing memberikan pengaruh signifikan bagi pengembangan aktivitasnya, karena itu usaha yang dilakukan adalah melaksanakan strategi untuk mencapai keunggulan bersaing. Alat untuk mendiagnostik keunggulan bersaing dan

162 L.Martin, R. West Gren, dan E.Van Duren,"Agribusiness Competitiveness A Cross National Boundaries", American Journal of Agricultural Economic, No.73 (5) 1458-71,1991, hlm 147 dan 148. diakses 15 Februari 2018.

163 Ibid. 
menemukan cara-cara meningkatkannya adalah rantai nilai (value chain) yaitu rantai nilai pemasok, rantai nilai perusahaan, rantai nilai penyalur, dan rantai nilai pembeli, dan cakupan aktivitas dalam mendesain, memproduksi, memasarkan dan mendistribusikan produknya yang disebut cakupan bersaing (competitive scope). ${ }^{164}$

Dalam kaitannya dengan paten yang dihasilkan oleh Perguruan Tinggi, invensi merupakan cakupan daya saing yang utama. Sedangkan cakupan daya saing dalam memproduksi, memasarkan dan mendistribusikan produknya adalah konsekuensi dari kualitas paten yang erat kaitannya dengan rantai nilai yaitu aktivitas yang relevan secara strategis untuk memahami perilaku biaya dan sumber diferensiasi yang potensial. Hal ini berarti keunggulan bersaing diperoleh apabila paten yang ditemukan lebih murah atau lebih baik dan mampu menghasilkan produk teknologi yang baru dibandingkan pesaing. Selanjutnya, pemasok memiliki rantai nilai (nilai hulu atau upstream value) yang menciptakan dan menyampaikan masukan yang dibeli dan digunakan di dalam rantai nilai perusahaan. Penyalur melakukan aktivitas tambahan yang mempengaruhi pembeli dan aktivitas perusahaan sendiri. Dasar terakhir untuk diferensiasi adalah perusahaan dan peran invesinya dalam hal ini paten dalam rantai nilai pembeli. Hal ini berarti meskipun harga lebih mahal dari pesaingnya tetapi paten tersebut tetap diminati karena mutu atau kualitas lebih baik dibandingkan produk teknologi sejenis.

Cakupan bersaing memiliki efek yang kuat pada keunggulan bersaing karena membentuk konfigurasi dan keekonomisan rantai nilai. Ada empat dimensi cakupan yang mempengaruhi rantai nilai, yaitu: ${ }^{165}$

“a. Cakupan Segmen, yaitu variasi produk yang dihasilkan dan pembeli yang dilayani.

b. Cakupan Vertikal, yaitu aktivitas dilaksanakan didalam perusahaan. Integrasi vertikal mendefinisikan pembagian aktivitas diantara perusahaan dan pemasok, penyalur, dan pembeli.

c. Cakupan Geografis, yaitu jajaran wilayah, negara, atau kelompok negara tempat perusahaan bersaing dengan menggunakan strategi terkoordinasi.

d. Cakupan Industri, yaitu jajaran industri terkait tempat perusahaan bersaing dengan strategi terkoordinasi."

Hubungan antara cakupan bersaing dan rantai nilai memberikan dasar untuk menjelaskan batasan unit usaha yang relevan. Unit usaha yang berbeda secara strategis dipisahkan untuk mempertimbangkan manfaat integrasi dan deintegrasi dengan cara

${ }^{164}$ Michael E Porter, Strategi Bersaing : Teknik Menganalisis Industri dan Pesaing, Alih Bahasa Agus Maulana, Jakarta : Erlangga, Jakarta, 1995, hlm 17.

165 Selengkapnya lihat Michael E Porter, Ibid, p.53-56. 
membandingkan antara hubungan dalam melayani segmen terkait, wilayah geografis, cakupan vertikal atau industri dan perbedaan dalam mata rantai yang paling cocok untuk melayani secara terpisah. Apabila perbedaan segmen produk atau wilayah geografis, maka pembeli memerlukan rantai nilai yang berbeda sehingga segmen menciptakan unit usaha. Misalnya rantai nilai yang diperlukan untuk melayani pembeli paten bagi kreasi teknologi yang canggih dengan kemampuan servis di dalam perusahaan berbeda dengan yang diperlukan untuk melayani pemakai bisnis kecil. Manfaat yang besar dalam integrasi vertikal meluaskan batasan unit usaha agar mencakup aktivitas hulu atau hilir, sedangkan manfaat yang lemah untuk integrasi menyiratkan bahwa tiap-tiap tahap merupakan unit usaha tersendiri. yaitu aktivitas dilaksanakan di dalam perusahaan. Misalnya invensi paten merupakan aktivitas rantai nilai pemasok, sedangkan manufakturnya adalah rantai nilai perusahaan. Demikian pula, manfaat yang besar untuk koordinasi seluruh dunia atas rantai nilai menyiratkan bahwa unit usaha yang relevan adalah bersifat global, sedangkan perbedaan antara negara atau wilayah yang membutuhkan rantai nilai berbeda menyiratkan sempitnya batasan unit usaha geografis. Misalnya paten dikembangkan di Jepang, tetapi memanufakturnya di banyak Negara sehingga memperoleh keunggulan biaya. Akhirnya, hubungan yang kuat antara satu unit usaha dengan unit usaha lainnya menyiratkan bahwa unit-unit tersebut harus digabungkan menjadi satu. Misalnya dalam pengembangan teknologi bersama melakukan pembuatan paten secara bersama-sama. Dengan demikian, unit usaha yang tepat dapat dijelaskan dengan memahami rantai-rantai nilai optimal untuk bersaing di tempat yang berbeda dan bagaimana rantai-rantai tersebut dihubungkan.

Penelitian di Perguruan Tinggi diarahkan untuk mengembangkan Ilmu pengetahuan dan Teknologi, serta meningkatkan kesejahteraan masyarakat dan daya saing bangsa. Penelitian tersebut dilakukan oleh Sivitas Akademika (dosen) sesuai dengan otonomi keilmuan dan budaya akademik. Penelitian dilaksanakan berdasarkan jalur kompetensi yaitu sesuai dengan keilmuannya dan kompetisi, misalnya Kementerian Riset, Teknologi dan Pendidikan Tinggi tiap tahun anggaran menyediakan dan penelitiah hibah bersaing. Hasil Penelitian diharpkan dapat bermanfaat untuk: pengayaan Ilmu Pengetahuan dan Teknologi serta pembelajaran; peningkatan mutu Perguruan Tinggi dan kemajuan peradaban bangsa; peningkatan kemandirian, kemajuan, dan daya saing bangsa; pemenuhan kebutuhan strategis pembangunan nasional; dan perubahan Masyarakat Indonesia menjadi Masyarakat berbasis pengetahuan. 
Hasil Penelitian wajib disebarluaskan dengan cara diseminarkan, dipublikasikan, dan/atau didaftarkan sebgai Hak Cipta atau paten oleh Perguruan Tinggi, kecuali hasil Penelitian yang bersifat rahasia, mengganggu, dan/atau membahayakan kepentingan umum. Hasil Penelitian Sivitas Akademika (dosen) yang diterbitkan dalam jurnal internasional, memperoleh paten yang dimanfaatkan oleh industri, teknologi tepat guna, dan/atau buku yang digunakan sebagai sumber belajar dapat diberi anugerah yang bermakna oleh Pemerintah berupa Hak Cipta karena merupakan pendukung daya saing global.

Kekayaan Intelektual memegang penting sebagai sarana persaingan dalam mendorong kemajuan IPTEK melalui inovasi-inovasi baru yang dapat diindustrikan; dansebagai alat peningkatan kesejahteraan perekonomian masyarakat, khususnya para peneliti (dosen) di Perguruan Tinggi yang mempunyai invensi. Dengan demikian ada keterkaitan yang erat antara perkembangan IPTEK dengan Kekayaan Intelektual karena perkembangan IPTEK tersebut akan diikuti dengan adanya perlindungan atas hasil atau kreasi tersebut, yang berupa Hukum Kekayaan Intelektual. Peningkatan hasil kreasi perkembangan IPTEK oleh dosen di Perguruan Tinggi, akan mempengaruhi semakin banyaknya Kekayaan Intelektual atas kreasi yang berwujud antara lain Hak Cipta dan Paten. Hal ini mengakibatkan pertumbuhan industri suatu negara semakin tinggi sehingga memiliki daya saing sebagai akibat keunggulan komparatif berupa kemajuan IPTEK yang mendapat perlindungan hukum Kekayaan Intelektual. ${ }^{166}$

\section{PENUTUP}

\subsection{Simpulan}

1. Hasil Pengembangan Ilmu Pengetahuan dan Teknologi di Perguruan Tinggi berpotensi untuk mendapat perlindungan kekayaan di bidang Hak Cipta dan Paten, tetapi tidak menutup kemungkinan diberikan hak melalui jenis Kekayaan Intektual lainnya.

2. Kreasi hasil pengembangan Ilmu Pengetahuan dan Teknologi yang mendapat perlindungan Kekayaan Intelektual dan didukung rantai nilai (value chain) dan cakupan bersaing (competitive scope) akan memiliki kualitas dan reputasi tinggi sehingga dapat meningkatkan daya saing global.

166 Bandingkan dengan Munsharif Abdul Chalim, "Pengaruh Perkembangan IPTEK Terhadap Permasalahan HAKI", Jurnal Dinamika Hukum Vol. 11 Edisi Khusus Februari 2011, p 56 tersedia dalam file:///C:/Users/kiki/Downloads/261-459-1-PB.pdf diakses 27 Januari 2018. 


\subsection{SARAN}

1. Perlu sosialisasi kepada sivitas akademika di Perguruan Tinggi tentang kreasi hasil pengembangan ilmu pengetahuan dan teknologi yang berpotensi mendapat perlindungan Kekayaan Intelektual.

2. Perlu upaya untuk mendorong sivitas akademika agar terus menghasilkan kreasi yang original dan baru yang berpotensi untuk mendapat perlindungan Kekayaan Intelektual, misalnya dengan memberikan insentif kepada inventor sehingga akan meningkatkan kualitas dan reputasi Perguruan Tinggi yang bersangkutan dalam menghadapi gobalisasi yang sarat dengan persaingan.

\section{DAFTAR PUSTAKA}

\section{Buku, Artikel}

Bambang Pratama, "Fair Use VS. Penggunaan yang Wajar dalam Hak Cipta". Tersedia dalam http://Business-Law.Binus.ac.id/2015/01/31/Fair-Use-VS-Penggunaanyang-Wajar-dalam-Hak-Cipta/ diakses 15 Januari 2019.

Candra Irawan, Politik Hukum Hak Kekayaan Intelektual Indonesia : Kritik Terhadap WTO/TRIP's Agreement dan Upaya Membangun Hukum Kekayaan Intelektual Demi Kepentingan Nasional, Mandar Maju, Bandung, 2011.

L.Martin, R. West Gren, dan E.Van Duren,"Agribusiness Competitiveness A Cross National Boundaries", American Journal of Agricultural Economic, No.73 (5) 1458-71,1991 diakses 15 Februari 2019.

Michael E Porter, Strategi Bersaing : Teknik Menganalisis Industri dan Pesaing, Alih Bahasa Agus Maulana, Erlangga, Jakarta, 1995.

Mieke Yustia Ayu Ratna Sari, "Pembangunan Kekayaan Intelektual (KI) Berbasis Teknologi Informasi Di Era Global", tersedia dalam https://media.neliti.com /media/publications/172839-ID-pembangunan-kekayaan-intelektual-ki-berb.pdf diakses 8 Januari 2019.

Munsharif Abdul Chalim, Pengaruh Perkembangan IPTEK Terhadap Permasalahan HAKI, Jurnal Dinamika Hukum Vol. 11 Edisi Khusus Februari 2011, hlm 56 tersedia dalam file:///C:/Users/kiki/Downloads/261-459-1-PB.pdf diakses 27 Januari 2019.

Pramdia Arhando Julianto, "Hak Kekayaan Intelektual dan Inovasi Tingkatkan Daya Saing Industri" tersedia dalam https://ekonomi.kompas. com/read/ 2017/ 07/ 18/ 224443126/hak-kekayaan-intelektual-dan-inovasi-tingkatkan-daya-saing-industri. diakses 7 Januari 2019.

Rahmi Jened Parinduri Nasution, Interface Hukum Kekayaan Intelektual dan Hukum Persaingan (Penyalahgunaan HKI), Rajawali Press, Jakarta, 2013. 
Rais Rozali, "Pengelolaan Kekayaan Intelektual" tersedia dalam https://zalirais.wordpress.com/2013/09/10/pengelolaan-kekayaan-intelektual/ diakses 2 Januari 2019.

Rendy Ivaniar Fakultas Hukum Universitas Brawijaya http://www.scribd.com/ doc/ 100516733/Kajian-Kritis-Rancangan-Undang-undang-Pendidikan-Tinggi. diakses 5 Januari 2019.

Riswandha Imawan, "Peningkatan Daya Saing": Pendekatan Paradigmatik- Politis, Volume 6, Nomor I, Juli 2002 (79-104) tersedia dalamfile:///C:/Users/kiki/ Downloads/11095-21113-1-PB\%20(2).pdf diakses 17 Januari 2019.

\section{Peraturan Perundang-undangan}

Undang-Undang Dasar 1945 Amandemen IV.

Undang-Undang Nomor 14 Tahun 2005 Tentang Guru dan Dosen.

Undang-Undang Nomor 12 Tahun 2012 Tentang Pendidikan Tinggi.

Undang-Undang Nomor 28 Tahun 2014 Tentang Hak Cipta

Undang-Undang Nomor 13 Tahun 2016 Tentang Paten. 